\title{
TARİH EĞİTIMI VE VATANSEVERLİK ÜZERİNE BAZI DÜŞÜNCELER
}

\section{Mehmet ELBAN*}

\section{$\ddot{O} z$}

$\mathrm{Bu}$ çalışmanın amacı tarih eğitimi ve vatanseverlik arasındaki ilişkileri yurt içi ve yurt dışı yazından hareketle farklı bakış açılarıyla ele almaktır. Bu kapsamda çalışmada bazı açılardan tarih eğitiminde vatanseverliğe dair farklı düşünceler ortaya konmuştur. Ayrıca millî tarih açısından tarih eğitiminde vatanseverliğin nasıl bir süreç izlediği de genel hatlarıyla incelenmiştir.

En başta bireyin ülkesine olan tutumunun gelişimsel olarak fiziksel çevreye dayalı benmerkezci dönem, sonrasında toplum merkezci ve objektif bakışın gelişebileceği geç ergenlik dönemlerinde oluştuğu görülmektedir. Bununla birlikte vatanseverliğin hem duyuşsal hem de bilişsel boyutu vardır. Bireyin ülkesine yönelik tutumunun vatanseverlik kavramıyla şekillenmesinde ise on dokuzuncu yüzyıl önemli bir yer tutar. Nitekim on dokuzuncu yüzyılda millî devletlerin gelişmesiyle, üstünde devlet kontrolünün tam olduğu millî eğitimlerin temel amaçlarından biri de genç nesillere vatanseverlik gibi değerleri kazandırmak olmuştur. Tarih eğitimi ise genç nesillere kazandırılacak olan vatanseverlik için önemli bir eğitim alanı hâline gelmiştir. Ancak vatanseverlik her ülke için aynı şekilde idealize edilmemiştir.

$\mathrm{Bu}$ bağlamda en genel anlamıyla kişinin ülkesine olan sevgisini ifade eden vatanseverliğe farklı manalar yüklendiği söylenebilir. Zira vatan ve vatanseverlik, ulusun dilinin konuşulduğu ve siyasi egemenliğin var olduğu coğrafya, ülkenin gerçek temsili kral veya hanedan, ülkenin siyasal sistemi, ülkenin politik kurumları ve ülke sembolleri ile özdeşleştirilebilmektedir. Vatan ve vatanseverliğe dair kurulan farklı manalar tarih eğitimi ve vatanseverliğinin boyutunu da etkilemiştir. Söz konusu farkl1lıkta eğitimsel, millî ve insani idealler ve devletlerin yönetim şekilleri önemli bir yere sahiptir. Son dönemlerde ABD'de tarih eğitimi ve vatanseverliğin Amerikanizm, çok kültürlülük, vatandaşlık bilgisi ve 11 Eylül saldırıları çerçevesinde değerlendirilmesi böylesi bir durumdur. Yine Avrupa'da tarih eğitiminde ulusların vatanından ortak Avrupa kültürüne doğru değiş̧en bir yönelim yaşanmaktadır. Sonuç olarak tarih eğitiminde vatanseverlik aktarımı ülkeden ülkeye farklılık gösterebilmektedir. Tarih eğitimi ve vatanseverlik açısından diğer bir önemli mesele de insani idealler ve tarih yöntem bilimidir. Geçmişten bu yana ileri sürülen görüşlerin geneli tarih eğitiminde verilen vatanseverlik duygusunun barışçı olması, diğer milletlere düşmanlık aşılamadan verilmesi üzerinedir. Tarih yöntem bilimi açısından ise tarih eğitiminde vatanseverlik duygusu kazandırılırken bilimsel yöntemin bir kenara bırakılmaması ilgili yazında belirtilmiştir.

Millî tarih açısından bakıldığında ise on dokuzuncu yüzyılda Tanzimat Fermanı, Islahat Fermanı diğer bir ifadeyle Osmanlıcılık fikriyle gelişen vatandaşlık kimliğinin tarih ders kitaplarına girdiği görülmektedir. Sultan II. Abdülhamit döneminde İslamcilık ve onu destekleyen Osmanlıcilık politikaları hâkim olmuştur. Anılan dönemin ders kitapları da Osmanlı hanedanı ve din merkezli bir boyut kazanmıştır. Yine mezkûr dönemde

\footnotetext{
* Dr.; İçişleri Bakanlı̆̆ı, melban111@gmail.com.
} 
Osmanlı devletinin sınırlarını gösteren haritalar vatanseverliği aşılayacak temel eğitim araçlarından biri hâline gelmiştir.

II. Meşrutiyet Dönemi ise yapısı itibarıyla vatansever bir formda olmasından ötürü tarih eğitimi de vatansever bir formda oluşmuştur. $\mathrm{Bu}$ dönemde tarih eğitimi ve vatanseverlik üzerine ileri sürülen görüşler, millî idealler, insani idealler ve tarih yöntemi açısındandır. Millî idealler açısından tarih eğitiminin vatanseverliği teşvik etmesi, insani idealler açısından tarih eğitimi ve vatanseverliğin barışçı olması, tarih usulü açısından ise tarih eğitimi ve vatanseverliğin tarih metoduna aykırı olmaması gibi düşünceler ifade edilmiştir. Cumhuriyet ile birlikte tarih eğitimi ve vatanseverlik Osmanlı hanedanı, meşrutiyet gibi değerler yerine, artık rejimin ve vatanın sınırlarının belli olduğu, millî kültür ve millî tarih merkezli yeni değerler üzerine gelişti. Ancak, 1930 sonrası Cumhuriyet tarihi dışındaki tarih ders kitaplarında sevgi duyulan vatana dair kurulan aidiyet bağı, bazı tarihsel dönemlerin vurgusunda farklılaşt1. II. Dünya Savaşı sonrası ise uluslararası etkiler, dünyada olduğu gibi Türkiye'de de tarih eğitiminde barışçıl vatanseverliği ve demokratik vatandaşlığ gündeme getirmiştir.

Anahtar Sözcükler: Tarih eğitimi, vatanseverlik, vatandaşlık.

\title{
SOME THOUGHTS ON HISTORY EDUCATION AND PATRIOTISM
}

\begin{abstract}
This study deals with the relationship between history education and patriotism with different perspectives from local and foreign literature. Within this framework, ideas regarding patriotism in history education were handled in some respects. Additionally, how patriotism in history education has been changed over time in terms of Turkish national history was examined.
\end{abstract}

At first, the attitude of an individual towards his/her country developmentally occurs in the period of the egocentrism that is based on the physical environment, then the socio-centric period and late adolescence period related with the development of objective view. Besides, patriotism has both affective and cognitive dimension. The nineteenth century holds an important place in shaping the attitude of an individual towards his/her country with the concept of patriotism. Hence, in the nineteenth century, with the development of national states, one of the main objectives of the national educations which controlled totally by the state was to inculcate the values like patriotism to younger generations. History education for younger generations has become an important educational area to inculcate patriotism. On the other hand, patriotism is not idealized in the same way for each country.

In this context, it can be said in general sense that different meanings to patriotism which means love of individual for his/her country were assigned. Thus, homeland and patriotism can be identified with the region in which national language spoken and political sovereignty exists, king or dynasty which assumes real representation of the country, political system, political institutions of the country and the country symbols. These different meanings for homeland and patriotism impressed history education and patriotism too. Educational, national and humanistic ideals and forms of governments keep an important place in these differences. Recently in the US, evaluating history education and patriotism in the light of Americanism, multiculturalism, citizenship and September $11^{\text {th }}$ attacks is such a case. Then again in the Europe, there is a changing orientation in history education from homeland of nations to common European culture. As a result it can be said that patriotism in history education varies from country to country.

\section{TF/Re}

Uluslararası Türkçe Edebiyat Kültür Eğitim Dergisi Sayl: 4/3 2015 s. 1302-1319, TÜRKIYYE 
Another important issue in terms of history education and patriotism is humanistic ideal and history methodology. In this context, general of the arguments from past to present are that patriotism in history education should be peaceful and not to inculcate hostility to other nations. As for history methodology, it is specified in the related literature that patriotism should not conflicted with scientific methodology.

From the perspective of Turkish national history, in the nineteenth century, citizenship identity which developed with the edicts of Tanzimat and Islahat, in other words Ottomanism, influenced history textbooks. Policies of Islamism and Ottomanism which support Islamism has been dominated in the era of Sultan Abdülhamit II. Textbooks in aforesaid era were based on the dynasty and religion. In this era, school maps showing the boundaries of the Ottoman Empire became one of the main educational tool to inculcate patriotism.

As to Second Constitutional Era, because of its patriotic structure, history education was also patriotic form. In this era, views on which put forward history education and patriotism were aspects of national, humanistic ideal and history methodology. It was expressed the ideas like history education should promote patriotism in term of national ideal; history education and patriotism should promote peace in term of humanistic ideal; and history education and patriotism should not be contrary to history methodology.

With the Modern Turkish Republic, history education and patriotism was based on new values which include the new regime, country's certain borders, national history and culture. However, after 1930, loyalty for homeland differentiated in emphasis of certain historical periods. After World War II, works of international organizations have brought peaceful patriotism and democratic citizenship to history education in Turkey as well as in the world.

Keywords: History education, patriotism, citizenship.

\section{Giriş}

Vatanseverlik millî eğitimlerin öğrencilere kazandırılacak önde gelen amaçlarındandır. $\mathrm{Bu}$ amaçların sistemsel olarak ortaya çıkışı millî devletlerin doğuşuyla yakından ilişkilidir. Çünkü millî devletlerin temel esaslarından biri bireylerin devletle olan vatandaşlık bağıdır. Vatandaşlık, bu bağın daha çok bilgi düzeyini oluştururken; vatanseverlik, duygusal boyutunu oluşturmaktadır. Vatanseverlik duygusunun yeni nesillere kazandırılmasında ise tarih eğitimi en etkili araçlardan biri olmuştur. Tabi bu birliktelik geçmişten itibaren, farklı tasarımları, bazı sorunları ve düşünceleri de beraberinde getirmiştir.

Bu çalışmada ise tarih eğitiminde vatanseverlik, eğitimsel ve millî idealler, tarih yöntem bilimi ve milli tarih açısından ele alınmıştır.

\section{Vatanseverlik Kavramı}

Vatanseverlik kavramının daha iyi anlaşılabilmesi için öncelikle vatanın ne olduğundan söz etmekte yarar vardır. Vatan bir milletin sosyal, maddi ihtiyaçlarını karşıladığı ve barındığ yerdir. Bununla birlikte vatan milletin atalarının eserleriyle duygusal manada beslendiği 
topraklardır. Diğer bir ifadeyle vatan, milleti geçmişin anılarıyla besleyen, maddi ve manevi ihtiyaçlarını karşılayan coğrafi mekândır (Öner, 2008: 261-262). Bu yönüyle vatan kavramının "ülke"den fark1, ona daha öte değerler atfedilmesidir (Üstel, 2004: 158). Sosyolojik veya sosyal sevgi olarak nitelendirilen vatanseverlik (Ergen, 2006: 150) ise bir insanın ülkesine fayda sağlayacak eylemlerde bulunmasıdır (Yıldırım, 2006: 23). Vatanseverliğin, insanın var oluşunu anlamlı kılan bir duygu olduğunu söyleyen Namık Kemal, onu her sevgiden önce tutar. Öyle ki kişinin yaşadığı çevreye dair güzellikleri görme saadeti hep vatan sayesinde mümkün olur (Taneri, 1993: 165). Diğer tanımlara bakıldığında, Alman tarihçi Heinrich von Treitschke'ye göre gerçek vatanseverlik siyasi oluşum ile iş birliğinde olmak, ataların başarılarını takdir etmek ve bu bilinci sonraki nesillere aktarmaktır (Özkırıml1, 2008: 43). Herder'e göre vatanseverlik imparatorlar ve monarklara layık görülen ülkenin genel iyiliğine yönelik büyük işler yapmadır (Viroli, 1997: 127). Fichte ise vatanseverliği "İnsan, milletinin yaşaması için kendi hayatını daima fedaya hazır olacaktır... İşte hakiki aşk budur... Kendinin ebedî olduğuna inanmayan insanda vatan aşkı olmaz...” diyerek tanımlamıştır (Fichte'den aktaran Ata, 2013: 3). Balkan Savaşları'nda dönemin eğitimcilerinden Satı Bey için vatanseverlik, vatanın maddi ve manevi unsurlarının her kapsamda ilerlemesini istemektir (Ülken, 1998: 181). Anlaşıllyor ki vatanseverlik farklı insanlar tarafından farklı şekillerde algılanabilir. Kimileri için vatanseverlik, ülkeye, vatana bağlılık, ülkenin kültürü için gurur hissetme, saygı ile ülke tarihini takdir ederek ondan övünç duyma, ona karşı bir aidiyet duygusu hissetme olabilirken, kimileri için siyasal bir bağl111ktan kaynaklanan sevgi anlamlarına gelebilir (Finn, 2007; Fonte, 1997; Lutovinov, 2006; Ravitch 2007'den aktaran Rapoport 2009: 27). Vatanseverliğin tanımındaki diğer önemli bir husus ise onun milliyetçilik ile olan ilişkisidir. Landau'ya göre vatanseverliğin milliyetçilik ile olan ilişkisi üzerine çalışma yapan araştırmacılar arasında uzun yıllardır süregelen bir tartışma vardır. İkisi arasındaki farkın vatanseverlikte ön plana çıkarılan vurgulamanın öncelikle ülkeye sonra millete; milliyetçilikte ise önce millete sonra ülkeye yapılıyor olmasıdır (Landau, 2009: 79). Benzer bir yaklaşımda Viroli'ye göre, milliyetçilik söylemi Avrupa'da on sekizinci yüzyıl sonlarında bir halkın türdeşliğinden hareketle kültürel birliği, vatanseverlik söylemi ise yüz yılı aşkın bir sürede bir halkın yaşam biçimine ve politik kurumlara olan sevgiyi merkeze alır. Başka bir ifadeyle vatanseverler için temel değer siyasi değerler ve bu değerlerin kazandırdığı özgürlükler iken, milliyetçiler için ise temel değer halkın kültürel ortaklığıdır (Viroli, 1997: 12).

\section{Tarih Eğitimi ve Vatanseverlik}

Tarih eğitiminde vatanseverlik duygusunun kazandırılmasının temelleri, milliyetçiliğin, millî devletlerin ve millî eğitimlerin gelişmesine değin uzanır. Nitekim siyasal milliyetçiliğin yükselişiyle, tarih bir bilimsel disiplin ve bir öğretim programı olarak okul programlarına 
önemli bir yer edinirken, diğer taraftan ona tarihsel bilgi ve becerilerin verilmesi dışında millî kimliğin inşasına dair vatansever vatandaş yetiştirme vazifeleri yüklenmişti (Safran, 2008: 14). Çünkü milliyetçi anlayışta millî eğitimin amacı yalnız bilgi vermek değildir. Millî eğitimin önemli bir amacı da gençlerin iradesini milletin iradesiyle birleştirmektir. Bu iradelerin bir araya getirilmesinde okul, ordu, polis önemli araçlardandır (Kedourie, 1971: 76). Tabi bu araçlardan en etkili olanlar aile ve okullardır (Öner, 2008: 261). Okullarda ise öğrencilerin vatanseverlik duygusu tarih dersleriyle kazandırılmaktadır (Tolstoy, 2011: 39). Diğer bir ifadeyle millî kimlik aktarımında, vatandaşların ülkesine karşı bağlılığında ve sorumluluklarında ihtişamlı tarihler, destansı zaferler, dram yüklü mağlubiyetler, kahraman liderler ve ötekileri içeren millî mitler önemli tarihsel anlatılar olurken; okullar da ulus inşasında vatansever tarih anlatılarının verildiği resmi kanallar olmuştur (Callan, 2002: 470). Ulus inşasında lokomotif görevi yapan kamu okullarıyla birlikte medya ve akran grubu diğer etki araçlarıdır. Lokomotif görevi yapan bu etki araçları üzerinde devletin tam veya kısmi kontrolü vardır. Modern devletler bu önemli etki araçlarını (medya, spor ve gençlik örgütleri ve ordu) gençlerin toplumsallaşmasında, istedikleri türden kimlik geliştirmesinde tam veya kısmen kontrol edebilmektedir. Böylesi bir kontrol, aşağıdaki gibi bir şemada gösterilebilir (Walkenhorst, 2004: 10).

Şekil 1. "Ulus İnşası Bağlamında Siyasal Toplumsallaşma" (Walkenhorst, 2004: 10)

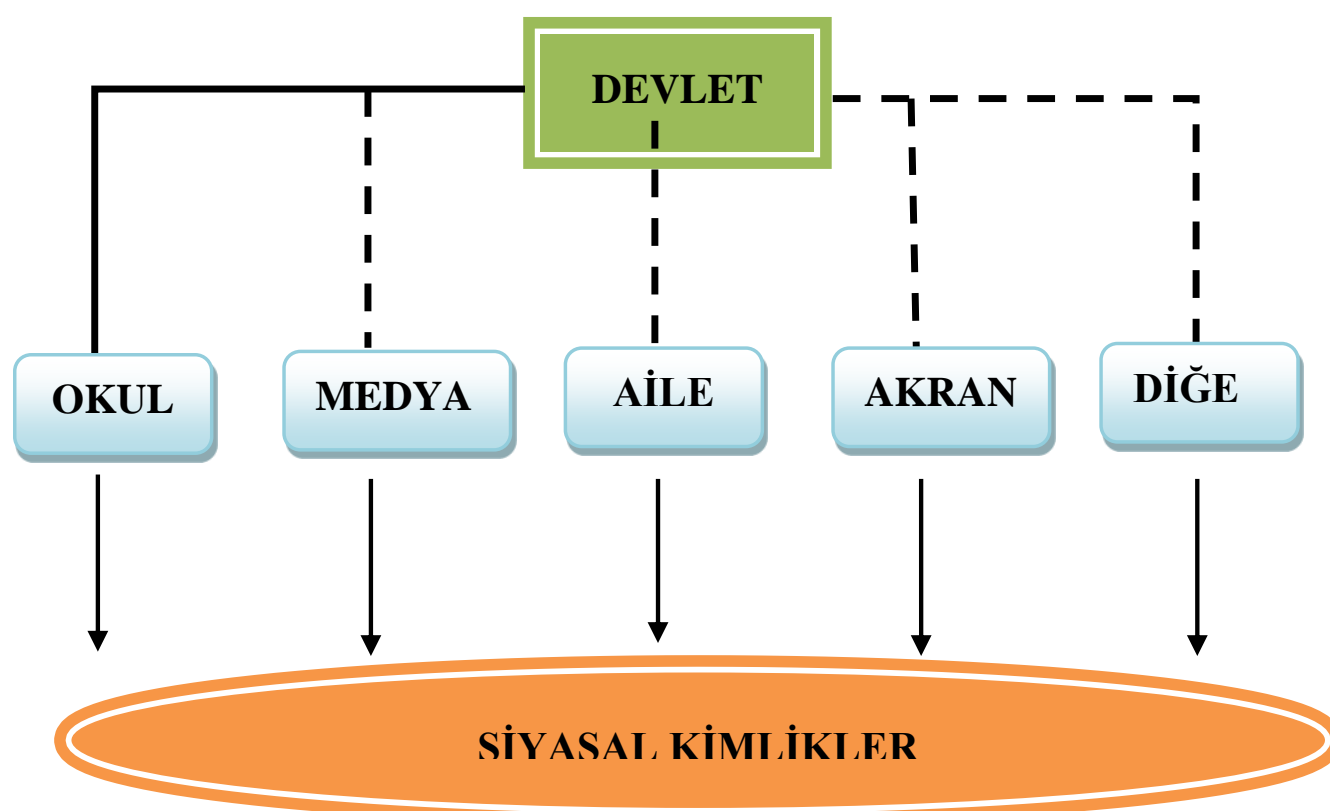

\section{Kişisel Kimlikler}

\section{Kolektif Kimlikler}

\section{Tam Kontrol}

Kısmi Kontrol

Etki 
Gelişimsel olarak bireyin ülkesine olan tutumu ele alındığında ise bazı evrelerin ileri sürüldüğü görülmektedir. Bu çerçevede Lay ve Purta, bireyin ülkesine yönelik duygularını Nugent, Hess ve Torney, Piaget ve Weil'in konuya ilişkin görüşlerinden yola çıkarak açıklamıştır. Buna göre ilk aşama benmerkezci aşama, çocuğun yaşadığı ülkesine yönelik anlayışı sıcakkanlı, dostça insanlar gibi fiziksel çevreye dayalıdır ve daha çok somut gözlemlerden ibarettir. Çocuklar, bilişsel düzeyde ülke ve sivil miras hakkında çok az bilgiye sahip olmasına karşın ülkesine karşı olumlu duygular geliştirirler. Çocuk toplum merkezci aşamaya geçişte ülkesine yönelik eleştirel olmayan pozitif görüşler kazanır. Çocuk, bu aşamada ergin dönemde, kendi millî tarihinin diğer ülkelerinkinden daha iyi olduğunu düşünür. Çocuğun nihai olarak ulaştı̆̆ı, bilişsel kazanımların daha ağırlıkta olduğu geç ergenlik aşaması ise, kendi millî tarihine ya da değerlerine objektif ve karşı olabildiği, kendi ülke tarihinin, değerlerinin olumsuz yönlerini hatalı bulabildiği dönemdir. Anılan dönemde çocuk, ülkesine karşı farklı bakış açıları geliştirerek, farklı düşüncelere varabilir; vatanını merkeze almaktan ziyade onu dünyanın bir parçası olarak görebilir (Lay ve Purta, 2001: 5). Diğer taraftan bireyin ülkesine yönelik sevgi gelişimi demokratik ve demokratik olmayan bir tarzda da gelişebilir. Çünkü vatanseverliğin hem bilişsel hem de duyuşsal boyutu vardır. Vatanseverliğin duyuşsal boyutta içerdiği sevgi ve aidiyet duygusunun şekli, bilişsel boyutta içerdiği demokratik olan ve olmayan bilgiler ile biçimlenmektedir. Demokratik olan ve olmayan vatanseverlik, duyuşsal boyutta aynı olsa da ikisini birbirinden farklı kılan bilişsel boyutta içerdiği bilgilerin niteliğidir (Yazıcı ve Yazıc1, 2010: 650).

Bireyin bu gelişimi göz önüne alındığında, okullar vatan aşk1, millet sevgisi, vatansever olmak, saygılı olmak, dürüst olmak ve adil olmak gibi değerleri öğrenciye kazandırılacak duyuşsal hedefler kapsamında değerlendirirler. Bu bağlamda hazırlanan programlar, açık olarak belirtilen veya belirtilmeyen toplumsal ve ahlaki değerleri öğrencilere öğretme ve benimsetme gibi amaçlarda olabilir (Akbaş, 2008: 9). Sungu'ya göre vatanseverlik gibi duyuşsal kazanımların çocuklara kazandırılmasında tarih dersi çok etkili bir araçtır. Tabiatıyla her millet tarihin bu gücünden yararlanmaya çalışır. Diğer taraftan millî tarihi, milletin geçirdiği aşamaları, vücuda getirdiği idealleri ve millî kültürü öğrenme; toplumu oluşturan bireyler ile millet arasında güçlü bir bağl1lık oluşturur. Böylece birey, tarihsel süreçte ait olduğu milletinin bütün fedakârlıklarını, yarattığı idealleri yakından hisseder. Mensup olduğu milletin tarihteki önemli olaylarının bilincinde olan birey, millet sevgisini, vatan aşkını daha içtenlikle yaşar (Sungu, 2002). Görülüyor ki millî bir çizgide verilen tarih eğitimi vatanseverliğin kazanımı için en etkili araçlardandır. Fakat bu noktada vatanseverliği teşvik eden bir tarih eğitiminin milliliği bazı açılardan sorgulanabilmektedir. 
Örneğin, Safran'a (2008: 14) göre tarih eğitiminin millî çizgide verilmesi gayet tabiidir. Ancak temel hareket noktası vatan ve millet sevgisinin insani değerlerle beraber verilmesi ve tarihin saptırılmamasıdır. Aynı doğrultuda Porath'a (2007) göre bir değer olarak vatanseverlik kavramının bazı temel koşullar altında verilmesi gerekmektedir. Tolstoy ise vatanseverlik duygusunun aktarmak için kullanılan tarih derslerinde ulusların kendilerini hep iyi ve haklı olarak gösterdiğini ve Avrupa uluslarında hızla gelişen vatanseverlik duygusunun savaşlara neden olacağını söylemiştir (Tolstoy, 2011: 39, 73). Merry'e (2009: 378) göre de tutucu yönde bir vatanseverlik, tarihi anlamada bir görmezlik, ülkeye içselleştirilememiş zoraki bir bağl1lık duygusu gibi sağlıksız tutumlar geliştirebilir. John Dewey ise bazı eğitim idealleri açısından vatanseverlik öğretiminin başka milletlere karşı düşmanlığa sebep olup olmayacağını ve Amerikan tarihi öğretiminin tarihsel gerçekler bağlamında ne derecede "Amerikanizmi” inşa edecek şekilde tasarlandığı üzerine durmaktadır (Dewey, 2014: 150-153). İnsani değerlerin tarih öğretiminde ve bu kanalla vatanseverlik boyutunda ifade edilmesine dair John Dewey'e göre tarih öğretiminden beklenen barışı teşvik etmesi, geçmişin bilgisi ile günümüzdeki ve gelecekteki problemlerin üstesinden gelmek için muhtemel çözümlere katkı sağlayarak askerî kahramanların romantik tarihsel anlatısından ayrılması ve öğretmenlerin de daha çok tarihin sosyal manasına odaklanmasıdır (Clopton ve Tsuin-Chen'den aktaran, Howlett 2008: 2). Wesley’e (2013: 12) göre yansitıcı sorgulamanın manevi babası olarak Dewey, kültürün yüzeysel aktarımını reddeder ve çocuklara toplum için önemli sorunların verilmesini ister.

Durkheim'e göre modern toplumların istediği ve toplumun yönetiminin istediği şekilde yetişen vatandaşın her şeyden önce iyi bir insan olması için çalışılmalıdır (Akyol, 2013: 11). Vatandaşlık sorumlulukları devletten devlete, demokrasi ve monarşiler gibi farklı yönetim şekillerinde farkl1lıklar göstermekle birlikte bazen benzerlikler de görülebilmektedir. Fakat nihai olarak vatandaş olmayan birey yoktur, her birey bir devlete bağlı ve birbirine benzeyen sadakat, bağlılık gibi sorumlulukları vardır (Durkheim'den aktaran Canal, 2013: 18). Durkheim'in tarih öğretimi görüşleri ele alındığında vatandaşlıkla ilgili ortak temalar görülebilir. Ata'ya (2013: 48) göre Durkheim için tarih öğretiminin öznesi millet ya da toplumdur ve tarih öğretimi millet ya da toplumun nesiller arası bağlılığını, ortak bilincini, birlik ve beraberliğini sağlayan bir araçtır. Ayrıca Durkheim tarih eğitiminde o toplumun önemli kişilerinin medeniyete katkılarının öne çıkarılmas1 görüşündedir (Ata, 2013: 43-47). Durkheim'in yukarıda bahsedilen görüşlerinden hareketle onun vatandaşl1k ve tarih öğretimine yönelik görüşlerinin ortak noktasını millet ya da toplumun oluşturduğu düşünülebilir.

Öte yandan Rousseau'ya göre vatandaşlığın ve vatanseverliğin beslendiği kaynaklar farklıdır. Vatanseverlik bireyde doğal olarak kendiliğinden gelişir ve vatandaşlığı daha güçlü 
kılar. Vatanseverlikten türemeyen, kurgulanmış bir kavram olan vatandaşlık ise duygusal olmaktan ziyade daha bilinçli yaşanan, akılcı bir iradenin tezahürüdür. Sonuçta iki kavram ne tamamen aynı ne de tamamen farklıdır (Özkırımlı, 2008: 41). Vatanseverlik, vatandaşlığın duyuşsal boyuttaki inanç, bağl11ı gibi duygusal yönünü oluşturduğu düşünüldüğünde (Üstel, 2004: 321), tarih eğitiminin vatandaşlık bilgilerine de katkı sağlaması beklenmektedir. Ancak ABD'de 1941'de yapılan bir araştırma da vatandaşlık ve Amerika tarihi derslerini almış öğrencilerin hükûmet mekanizmasının işleyişine ve anayasaya dair yeterli düzeyde bilgi sahibi olmadıkları gözlenmiştir. Söz konusu bulgu John Dewey'in endişelerini yansıtmıştır (Barr, Barth ve Shermis, 2013: 17). Bu bağlamda sosyal bilgiler dersi içinde bir tartışma süre gelmiştir. Süren tartışmalar farklı yaklaşımları da beraberinde getirmiştir. Bunlardan biri tarihsel anlatılarda inançların ön plana çıktığı temel amacın iyi vatandaşlık öğretimi olduğu "Vatandaşlık aktarımı olarak sosyal bilgiler öğretimi”dir. Diğer bir yaklaşım ise sosyal bilgilerin nasıl yorumlanıp kullanacağını bilen, sosyal bilimcilerin düşünme yöntemlerini öğrenmiş vatandaşlar yetiştirmeyi amaçlayan "Sosyal bilimler olarak sosyal bilgiler öğretimi”dir. Söz konusu yaklaşım 1915'lerdeki sosyal bilgiler derslerinin efsaneler ve propagandaları bırakarak, akademik tarih öğretilmesini amaçlayan "Yeni Tarih" anlayışının etkilerini yansıtmaktadır. Temel kaynaklara inen, tarihsel yorum analizi gelişen, tarihin içerik ve yöntemini bilen öğrencilerin daha iyi bir vatandaş olacağı düşünülmektedir. Diğer bir yaklaşım ise eleştirel düşünceyi önceleyen, sosyal problemlere dahli gerekli gören "Yansıtıcı araştırma olarak sosyal bilgiler öğretimi”dir. Vatansever öğretmenler tarafından eleştirilen bu yaklaşıma göre iyi bir vatandaşlık için tarih değil, problemler, sosyal sorunlar çalışılmalıdır (Barr vd., 2013).

Diğer taraftan ABD'de tarih eğitimi, vatandaş yetiştirme amaçlarıyla şekillenirken ABD'deki çok kültürlü yapı da tarih dersi içeriğinin oluşturulma aşamalarına yön vermiştir (Sungur, 2012). Bu noktada temel tartışmalardan biri de, ABD'de çok kültürlü tarih eğitiminin, demoktratik vatanseverliğin, tarihsel bilgi ve tarih yöntem biliminin nasıl bir dengede verilmesi gerektiği üzerinedir (Callan, 2002; Levisohn, 2003; Giarelli ve Justice, 2003). 11 Eylül saldırısından sonraki ortamda ise tarih öğretimi ve vatanseverlik muhafazakârların dikkatini verdiği konu olmuştur (Barton ve Levstik, 2004: 62). ABD'de vatanseverlik eğitiminde aktarılan vatansever insan profili, her yaştaki insanın ülkenin kanunlarına uyması, ülkesine sayg1 duyması (Lamachia, 2001: 7); ülkesini en iyi yer yapmaya çalışması, seçimlere aktif katılım sağlayarak oy vermesi, ülkenin önem atfettiği sembollerine sayg1 duyması, ülke bayrağını saygı ile selamlaması, Amerikan tarihini öğrenmesi, Amerikan kahramanlarını okuması, ülkesini geliştirmeye çalışması ve devlet yönetiminin, hükümetin nası1 çalıştığını öğrenmesi olarak belirtilmiştir (Raatma, 2000). 
Britanya'da ise hükûmet tarih derslerinin öğrencilere Britanya kimliğini ve ülke sevgisini geliştirmesi yönünde görüşler söylerken Londra Üniversitesi Eğitim Enstitüsündeki akademisyenler bu görüşü paylaşmamışlardır (www.telegraph.co.uk). Sovyet sonrası Rusya'nın ulus inşası sürecinde ise 1992-2004 yılları arasında okul ders kitaplarında millî kimlik ve vatanseverlik kazanımı üzerinde durulduğu görülebilir (Zajda, 2007). Genel olarak Avrupa'da ise tarih eğitimi ülkelerin eğilimlerine göre farklılık gösteren bir milliyetçilikten Avrupalılık istikametine doğru bir dönüşüme girmiştir (Pingel, 2003; Özyürek, 2006). Bu bağlamda 1996 yılından itibaren Tarih eğitimi ile ilgili yürütülen projelerde bir Avrupa kimliği inşası amaçlanmıştır (Yılmaz, 2007). Vatanseverlik ya da vatandaşlık eğitimi de bu dönüşümden etkilenmiştir.

\section{Millî Tarihte Tarih Eğitimi ve Vatanseverlik}

Orhun Abideleri'nde Ötüken'in korunmasına yönelik yer alan ifadeler toprak ile vatan ve vatan ile millet arasında bağl1lıkların kurulduğunu göstermektedir. Anılan ifadeler ve kurulan bağlılık Göktürkler'de vatan ve başkent kavramlarının varlığının göstergesi olarak görülebilir (Türkmen, 2013: 31). Yine, Kaşgarlı Mahmud'un Divan-ı Lugat-it Türk adlı eseri Türk dilini, kültürünü, askerini yücelterek Türk kimliğini dile getirmiştir. Millî gurur kaynaklarını sıralandıktan ve millî kimlik unsurlarını yücelttikten sonra Kaşgarlı Mahmud, eserinde Türk dünyası haritası vererek bugünkü tarih kitaplarındakine benzer toprak kimlik ilişkisi kurmuştur (Güvenç, 2010: 118). Zira milliyetçilikte haritalara sembolik bir anlam atfedilmektedir (Anderson, 1995: 190-195; Copeaux, 1998: 69). Ancak günümüz manasında tarih eğitimi ile vatanseverlik aktarımına bakıldığına, en dikkat çeken olay Osmanlı aydınlarının ve klasik devlet anlayışının on dokuzuncu asırda gelişmekte olan millî devletlerden etkilenmesidir.

Osmanlı devletinde on dokuzuncu yüzyılın ikinci yarısında Batı'dan gelen milliyetçilik akımıyla toprak ile üzerinde yaşayanlar arasında bağ kurulmuştu (Güvenç, 2010: 23). Bahsedilen etkiyle vatanseverlik eğitiminin planlı bilinçli bir şekilde programlanması Tanzimat dönemi ve Osmanlıcılık fikrini benimseyen aydınlar ile başlamıştı (Yazıcı ve Yazıcı, 2010: 649). Tanzimat Fermanı ile hiçbir ayrım gözetmeksizin herkese devlet eliyle siyasi bir kimlik, Osmanlı devlet vatandaşlığı verilmişti (Karpat, 2009: 64). Islahat Fermanı ile de Fransız Devrimi'nin bir ürünü olarak Osmanlı Devleti'ndeki insanların yurttaşlığında gönül bağı esas alınmıştı (Vatandaş, 2004: 113). 1869'da Osmanlı vatandaşı olanlardan doğanları Osmanlı vatandaşı sayan Tabiiyet-i Osmaniye Kanunu çıkarılmıştı (Karal, 1995: 177). Yine 1869'da çıkarılan Maarif-i Umumiye Nizamnamesi ile Sibyân Mekteplerinde tarih dersi okutulmaya başladı (Türk, 2013: 87). Sıbyân Okullarında okutulan Muhtasar Târih-i Osmanî ve Rüştiye’ye de Târih-i Umûmî ve Târih-i Osmanî isimli tarih dersleri ile Osmanlı vatandaşı kimliği 
oluşturmak istenmişti (Safran, 2002: 936). Sözü edilen dönemde Namık Kemal vatanseverliğin öncüsü olarak görülmüştü (Lewis, 2000: 141). Nitekim vatanseverliğe dönüşüm Namık Kemal'in Vatan Yahut Silistre adlı piyesinde anlatılmıştır ve vatanseverlik duygusunun gelişimine katk1 sağlamıştır (Karpat, 2009: 46; Vatandaş, 2004: 220). Onun vatanseverliğindeki vatan Osmanlı toplumundan çok Osmanlı topraklarını ifade etmiştir (Ahmad, 2006: 60; Lewis, 2000: 141). Ancak bununla beraber Namık Kemal'in vatanseverliği bir taraftan da İslami nitelikteydi (Lewis, 2000: 141). Vatansever ve meslek sahibi insanlar yetiştirmek mezkûr dönemde eğitimin amacıydı (Karpat, 2009: 28, 29).

Sultan II. Abdülhamit Dönemi’nde ise Osmanlıcılık, İslamc1lık ve Türkçülük siyasi fikirleri eğitimi etkilemişti. İlköğretimde "İslamcılık", ortaöğretimde "Osmanlıcılık"; dönemin sonuna doğru ise "İslamcılık" ve "Osmanlıcılık" ile birlikte "Türkçülük" okulların amaçları arasında yer almıştır (Kodaman, 1991: 164). İslamcılık ve Osmanlıcılık tarih ders kitaplarını da etkilemişti. Dolayısıyla tarih ders kitaplarında hanedan tarihi ve İslam vurgusu ön plandaydı (Alkan, 2009: 393). Bu dönemde yine devlet kimliğini halka aşlamak için haritalar, müzik, padişah tuğraları birer araç olmuştu. Sultan II. Abdülhamit Dönemi’nde eğitim sistemine önce kıta haritaları, sonra devletin tüm topraklarını gösteren logo haritalar girerek, vatan düşüncesinin gelişmesine katkı sağlamıştı. Vatan düşüncesinin oluşmasında önemli rol oynayan haritalar, öğrencilerin Osmanlı devletinin altın çağı ile mevcut durumunu mukayese etmesine de firsat verebilmişti (Fortna, 2005: 210-245). On dokuzuncu yüzyılın genelinde ise Osmanlı vatanseverliği dönemin büyük bölümü boyunca kendisini göstermişti. Mütevazı sonuçlar doğuran vatanseverliğin en önemli unsuru, Osmanlı devletinin iyiliği ve ilerlemesi için gayret göstermek olan Osmanlıcılık fikrinin yansımasıydı (Landau, 2009: 80)

1908 sonrası dönemde de Osmanlıların egemen olduğu siyasal coğrafyayı kapsayan vatan anlayışı, sözleşmeci (siyasal) bir ulus ve yurttaşlık anlayışı üzerine temellendirilmişti. (Üstel, 2004: 321-322). İttihat ve Terakki'den milletvekili olan Hüseyin Cahit Yalçın Meşrutiyetin farklı unsurları arasındaki bağları kuvvetlendirmek ve Osmanlı Devleti'ni dağılmaktan kurtarmak için yapılanın vatanseverlik devrimi olduğunu söylemektedir (Yalçın, 2008: 91). Hâliyle anılan dönemde tarih eğitimi, vatan sevgisini kazandırmak için önemli bir araç hâline gelmişti (Türk, 2013: 199). Osmanlıcılık fikrinin bir yansıması olarak Osmanlı adının bilinçli kullanıldığ 1913 tarihli Tedrisat-1 İptidaiye Kanun-1 Muvakkatı'nda (İlköğretim Geçici Kanunu) yer alan coğrafya, "Osmanlı Coğrafyası”, tarih; "Osmanlı Tarihi” bir Osmanlı vatandaşlığı inşa etmeyi hedeflemişti (Çelik, 2008: 360; Üstel, 2004: 29). Aynı doğrultuda Türk eğitim tarihinde gerek fikirleri gerekse uygulamaları ile iz bırakmış, II. Meşrutiyet Dönemi'nin saygın eğitimcilerinden biri olan Satı Bey, çocuklara her şeyden evvel bir değer 
olarak vatanseverlik eğitimi verilmesini istemişti (Ergün, 1987: 4). Satı Bey’e göre savaş gibi felaket zamanları vatanseverlik duygusunu kuvvetlendirmek için en uygun zamanlardı ve çocuklara vatan sevgisini aşılamanın yolu vatan tarihi ve coğrafyasıydı (Ülken, 1998: 181, 183). Sat1 Bey'in vatanseverliğinde Fichte'nin etkisini görmek mümkündü (Ata, 2009: 5). Ancak Satı Bey vatanı Fichte'nin düşündüğü gibi tanımlamıyordu. Fichte, vatanı Alman dilinin konuşulduğu yerler olarak tanımlarken Satı Bey Osmanlıcılık fikrinden hareketle vatanı Osmanlı Devleti'nin idaresi ve tarihinde görüyordu (Kuşçu, 2009: 42-43). Diğer taraftan Satı Bey, millî eğitimde verilen vatanseverlik duygusunun başka uluslara nefret üzerine kurulmamasına dikkat çekiyordu (Binbaşıŏlu, 2009: 323). Satı Bey'in bu görüşü Tolstoy'un vatanseverlik ile ilgili görüşlerine benzemektedir. Yine, mezkûr dönemde eğitimcilerden Sabri Cemil benzer bir yaklaşımla tarih öğretiminin amacının Osmanlı vatandaşlarına vatanseverlik kazandırmak olduğunu belirtmişti (Altın, 2013: 26). II. Meşrutiyet Dönemi'nin önde gelen eğitimcilerinden İsmail Hakkı Baltacıŏlu ise genç nesillere vatanseverlik aşılamanın yolu olarak vatan duygusunun somutlaştırılmasını gösteriyordu. Ona göre, oyunlar, bayrak, millî tarihten önemli bir kişiye ait fotoğraf çocuklarda vatanseverlik duygusunu geliştirecekti (Baltacioğlu, 1995: 62-63). Buna karşın Ahmed Refik, okullarda genç nesillere Alman anlayışıyla vatan ve millet sevgisi verilirken tarih usulünden ödün verilmemesinin önemini vurgulamıştı (Çalen, 2013: 153-154)

II. Meşrutiyet Dönemi'nde Balkan Savaşları sonrası Osmanlıcılık anlayışındaki acı deneyim, vatanseverlik anlayışını değiştirmişti (Üstel, 2004: 321-322). Zira Osmanlıcılık fikrinden sonra Türkçülük, Balkan Savaşları'nda Rumeli'nin kaybedilmesiyle kaçınılmaz bir politika olurken (İnalcık, 2009: 156) bu dramatik atmosfer Osmanlı'da millî devlet fikirlerinin ve milliyetçiliğin uyanmasını tetiklemişti (Ortaylı, 2011: 69). Bu bağlamda dönem içerisinde ders kitaplarına bakıldığında “onlar/ötekiler” olarak Yunanlılar, Bulgarlar, Sırplar, Karadağlılar ve onların işgal ettikleri topraklar, ortak acı olarak yapılan zulümlerden çizimler, Bulgarların yaptığı zulümler, son kale, asli vatan Anadolu'nun korunmasına yönelik sorumluluklar ders kitaplarında yer almıştı (Alkan, 2013: 168, 169). Mezkûr dönemde Türkçülüğün tarih eğitimine yansıması ise siyasi yazımlarda olduğu kadar yansımamış ve yüzeysel kalmıştı (Çalen, 2013: 299; Şengül, 2006: 259)

Balkan Savaşları'ndan sonra yaşanan acı deneyimlerden Birinci Dünya Savaşı sonunda oluşan mütareke şartları dönemine gelindiğinde artık millet için tek yaşam alanı gerçek vatan Anadolu ile milletin tarihi millî eksenine dayandırılmıştı (Akbayrak, 2009: 208). Vatanın Anadolu ile sınırlanması ile artık Türklerin Anadolu'daki tarihini ele alan bir millî tarih anlayışı düşünülmeye başlandı (Arık, 1992; Yinanç, 2011: 189-196). Cumhuriyet Dönemi’ne 
gelindiğinde vatanın sınırları belirlenmişti. Artık Namık Kemal'in vatan anlayışında olduğu gibi Osmanlı Devleti'nde vatan orduların gidebildiği her yer değil; Atatürk'ün vatan anlayışı, sınırları belli olan “Misak-1 Milli”ydi (Aydemir, 2008: 132-133). Cumhuriyet Dönemi'nde ulus ve vatandaşlık anlayışında ise Fransız ve Alman tarzının etkileri görünür hâle gelmişti (Üstel, 2004: 322; Uluç, 2012: 27).

Cumhuriyet Dönemi'nde 1926'da ilkokul programında yer alan "Yurttaşl1k Bilgisi" dersiyle çocuklara vatanseverlik değerini kazandırma, vatandaş haklarının ve sorumluluklarının neler olduğunu benimsetme ve yeni devletin yönetim anlayışı hakkında bilgi verme, Cumhuriyet ilkelerinin içselleştirilmesi amaçlanmıştı. "Yurt Bilgisi” dersinin yanı sıra "Tarih" ve "Coğrafya" dersleri de rejimin gereksinim duyduğu ve niteliklerini belirlediği vatandaş1 yetiştirmek için bu amaca hizmet etmişti (Keleşoğlu, 2008: 24). 1931 y1lında liseler için hazırlanan Türkiye Cumhuriyeti Tarihi ders kitabında tarihsel bilgi ve becerilerin yanı sıra Osmanlı ümmetinden Türk milletine dönüşümde, öğrencilere Cumhuriyet rejiminin siyasal ve toplumsal düzenine ve onun temel ilkelerine bağlı bir vatanseverliğin benimsetilmesi amaçlanmıştı (Aslan, 1992: 181). Bununla birlikte önemli bir amaç da millî kültürün aktarılmasıydı (Sakaoğlu, 1992: 53). Ancak Cumhuriyet Dönemi'nde vatan sınırları belli hâle gelmiş olsa da, vatana dair aidiyet bağını sağlayacak millî tarih anlayışında bazı farklılıklar ortaya çıkmıştı. 1930 ve sonrası tarih ders kitaplarına da yansıyan farklılık en temelde vatana dair aidiyet bağı sağlayacak tarihsel dönemlere yapılan vurgunun yoğunluğundan kaynaklanıyordu (TTK, 1930; TTK, 1931; Akınc1, 2013: 97; Türkdoğan, 2005: 87,109; Bilgili, 2014: 2; Bolat, 2012: 232). II. Dünya Savaşı sonrasında ise yaşanılan acı tecrübelere karşı 1946'dan sonra UNESCO'nun çalışmaları (Safran ve Ata,1996: 14), 1992 yılında Talim Terbiye Kurulunun çalışmaları ile 2001'deki Avrupa Birliği Bakanlar Komitesinin tavsiye kararının Türkiye'de sosyal bilgiler ve tarih eğitiminde önemli etkileri olmuştu (Safran, 2008: 19). Mezkûr gelişmeler, Tolstoy'un işaret ettiği barışçıl vatanseverliğin hem dünyada hem de Türkiye'de tarih eğitimi için konuşulmasını sağlayan faktörlerdendi. Yine 1990'larda tıpk1 1940'larda ABD'deki gibi hükûmet sistemlerinin öğrenilmesini destekleyen bir tarih eğitimi ilgisi oluşmuş ve Türkiye de sözü edilen gelişmelerden etkilenmişti. Bu kapsamda tarih eğitiminin Türkiye Cumhuriyeti'nin siyasal ve hukuk sistemine ve demokrasinin öğrenilmesine katk1 sağlaması öngörülmüştür (Güven, 2014: 162). Böylelikle bahsedilen gelişmeler sonrası, tarih eğitiminde millî değerler ile birlikte demokratik vatandaşlık ve barışçıl vatanseverlik, önemli bir ideal hâline gelmiştir. 


\section{Sonuç}

Tarih eğitiminde vatanseverlik aktarımının yeri pek çok eğitimci, araştırmacı, sosyal bilimci tarafından tartışılmıştır. Genel geçer bir eğitimsel ideal ortaya konmasa da, sıklıkla belirtilen ideal vatanseverlik aktarımının, tarihsel gerçekleri saptırmadan, ötekilere karşı bir düşmanlık yaratmadan verilmesidir. Aynı zamanda tarih eğitiminden beklenen bilinçli bir vatandaşlık eğitimine katkı sağlamasıdır.

Tarih eğitiminde vatanseverlik aktarımının nasıl olduğuna yönelik ise devlet yönetimlerinin, savaş gibi önemli tarihsel dönemlerin, millî ideallerin ve eğitimsel ideallerin tarihsel dönemlerin değişiklik göstermesinden ötürü farkl1lıklar ve benzerlikler olabileceği sonucuna varılmıştır. Çünkü monarşilerin, cumhuriyetlerin, kozmopolit devletlerin, savaş koşullarının vatansever vatandaşlar için biçtiği rollerin tamamen aynı olması beklenemez. Ancak genel olarak hepsinde kahramanlıklar, zaferler, sorumluluklar, fedakârlıklar, ortak acılar gibi tarihsel anlatılar az veya çok kullanılmıştır.

Millî tarih açısından bakıldığında ise on dokuzuncu yüzyılda Osmanlıcılık fikriyle şekillenen vatanseverliğin, tarih ders kitaplarında yer aldığı görülmektedir. Sultan II. Abdülhamit Dönemi'ne gelindiğinde tarih eğitiminde vatanseverliğin temelini Osmanlı hanedanlığ ve din oluşturmuştur. İkinci Meşrutiyet Dönemi’nde, tarih eğitimi vatansever bir çizgide verilmiştir. Balkan Savaşları'nın dramatik sonuçları, işgaller, ortak acılar ve ötekiler olarak ders kitaplarına yansımıştır. Osmanlıcılık fikrinin terk edilmesiyle hızlıca gelişen ve Cumhuriyet Dönemi'nde nihayete eren millî devlet vatandaşlı̆̆ı, kendisine uygun tarihsel anlatıları da beraberinde getirmiştir. Cumhuriyet Dönemi’nde Misak-1 Milli sınırlarını kapsayan ve rejiminin benimsenmesini esas alan tarihsel olaylar ve anlatılar tarih ders kitaplarına girmiştir. 1930 sonrası tarih ders kitaplarına da yansıyan tarih yazımlarında sevgi duyulan vatanın tarihine yapılan referanslar, tarihsel dönemler ve olayların yoğunluğunda farklılık göstermiştir. 1940 sonrasında ise uluslararası kuruluşların çalışmaları tarih eğitiminde demokratik vatandaşlık ve barışçıl vatanseverlik gibi idealleri gündeme getirmiştir.

\section{Kaynaklar}

AHMAD, F. (2006). Bir Kimlik Peşinde Türkiye. (çev. S. C. Karadeli,). (1. Baskı). İstanbul: İstanbul Bilgi Üniversitesi Yayınları.

AKBAŞ, O. (2008). Değer Eğitimi Akımlarına Genel Bir Bakış. Değerler Eğitimi Dergisi, $6(16), 9-27$.

AKBAYRAK, H. (2009). Milletin Tarihinden Ulusun Tarihine-İkinci Meşrutiyet'ten Cumhuriyet'e Ulus-Devlet İnşa Sürecinde Kurumsal Tarih Çalışmaları. İstanbul: Kitabevi Yayınları.

AKINCI, A. (2013). Türk İslam Sentezinde Tarih ve Kimlik. Bursa: Ekin Yayınları. 
AKYOL, C. (2013). Emile Durkheim'e Göre Eğitim. (ed. Bahri Ata). Emile Durkheim; Üçüncü Fransa Cumhuriyeti’nde Ö̈̆retmenlerin Eğitimcisi ve Eğitim Görüşleri içinde (s. 7-16). Ankara: Pegem Akademi Yayınları.

ALKAN, M. Ö. (2013). II. Meşrutiyet’te Resmi İdeoloji, Resmi Tarih ve Eğitim. (2. Bask1). (ed. Vahdettin Engin, Ahmet Şimşek). Türkiye'de Tarih yazımı içinde (s. 221-336). İstanbul: Yeditepe Yayınları.

ALTIN, H. (2013). II. Meşrutiyet Pedagoglarından Sabri Cemi ve Amelî Fenn-i Tedris-i. Turkish Studies, 8(2), 19-35.

ANDERSON, B. (1995). Hayali Cemaatler-Milliyetçiliğin Kökenleri ve Yayılması. (çev. İ. Savaşır). (2. Bask1). İstanbul: Metis Yayınları.

ARIK, R. O. (1992). Türk Milliyetçiliği. (2. Bask1). İstanbul: Dergâh Yayınları.

ASLAN, E. (1992). İnkılap Tarihi ve Atatürkçülük Dersinde Kullanılan Kitapların Değerlendirilmesi. Adem, M., Karakütük, K. (Ed.). Ortä̈ğretim Kurumlarında Inkılap Tarihi ve Atatürkçülük Öğretimi ve Sorunları içinde (s. 179-194). Ankara: Türk Eğitim Derneği Yayınları.

ASLAN, E. (2006). Neden Tarih Öğretiyoruz? Dokuz Eylül Üniversitesi Buca Eğitim Fakültesi Dergisi, 20. 162-173.

ATA, B. (2009b). Fichte’nin Eğitim Üzerine Düşünceleri ve Türkiye'deki Yansımaları. (ed. Bahri Ata). Ankara: Pegem Akademi Yayınları.

ATA, B. (2013). Emile Durkheim'e Göre Eğitim. (ed. Bahri Ata). Emile Durkheim; Üçüncü Fransa Cumhuriyeti’nde Öğretmenlerin Ĕ̆itimcisi ve Eğitim Görüşleri içinde (s. 3550). Ankara: Pegem Akademi Yayınları.

AYDEMIR, Ş. S. (2008). Atatürk Milliyetçiliği. (der. Ahmet Köklügiller). Milliyetçilik Nedir, Ne Değildir? (1. Baskı) içinde (s. 130-133). İstanbul: IQ Kültür Sanat Yayıncılık.

BALTACIOĞLU, İ. H. (1995). Talim ve Terbiyede İknlap. (haz. R. Canım, R. Y. Kıncal). İstanbul: MEB Yayınları.

BARR, R., BARTH, J. L. ve SHERMİS, S. S. (2013). Sosyal Bilgilerin Doğası. (1. Bask1), (çev. ed. Cengiz Dönmez). Ankara: Pegem Akademi Yayınları.

BARTON, K. C. ve LEVSTIK, L. S. (2004). Teching History for The Common Good. New Jersey: Lawrence Erlbaum Associates, Inc., Publishers.

BİLGíl̇, A. S. (2014). Eğitim Programlarımızda Türk-İslâm Sentezi Meselesi (1980-2000 Yılları Arasındaki Tartı̧̧malara Bir Projeksiyon). e-Kafkas Eğitim Araştırmaları Dergisi, 1(1), 1-13. 07 Ekim 2014 tarihinde http://www.kafkas.edu.tr/dosyalar/egitim dergi/file/kafead_2014_1_1_1-13.pdf adresinden alınmıştır.

BOLAT, B. S. (2012). Tanzimat'tan Demokrat Partiye Kültür Politikaları ve Tarih Anlayışları. The Journal of Academic Social Studies, 5(8), 231-247.

CALLAN, E. (2002). Democratic Patriotism and Multicultural Education. Studies in Philosophy and Education, Kluwer Academic Publishers, 21, 465-477.

CLARKE, K. U. (1918). Teaching the Child Patriotism. Kessinger Publishing.

CANAL, M. (2013). Emile Durkheim'e Göre Meslek Ahlakı. (ed. Bahri Ata) Emile Durkheim; Üçüncü Fransa Cumhuriyeti'nde Öğretmenlerin Eğitimcisi ve Eğitim Görüşleri içinde (s. 17-34). Ankara: Pegem Akademi Yayınları.

COPEAUX, E. (1998). Tarih Ders Kitaplarında (1931-1993) Türk-Tarih Tezinden Türk İslam Sentezine. (2. Bask1). İstanbul: Tarih Vakf1 Yurt Yayınları.

\section{TFip}

Uluslararası Türkçe Edebiyat Kültür Eğitim Dergisi Sayl: 4/3 2015 s. 1302-1319, TÜRKİYE 
ÇALEN, M. K. (2013). II. Meşrutiyet Döneminde Türk Tarih Düşüncesi. İstanbul: Ötüken Yayınları.

ÇAPA, M. (2002). Cumhuriyet'in İlk Yıllarında Tarih Öğretimi. Ankara Üniversitesi Tiirk İnkllâp Tarihi Enstitüsü Atatürk Yolu Dergisi, 29-30 (Mayıs-Kasım), 39-55.

ÇELİK, H. (2008). Cumhuriyet Dönemi Vatandaşlık Eğitiminde Önemli Adımlar. SAÜ FenEdebiyat Dergisi, 1, 359-369.

DEWEY, J. (2014). Günümüzde Eğitim-Öğretmenlik Mesleğindeki Görev ve Sorumluluklar. (2. Bask1). [ed. Joseph Rather; (çev. ed. Bahri Ata, Talip Öztürk; çev. Ebru Gençtürk)]. Ankara: Pegem Akademi Yayınları.

ERGEN, G. (2006). Eleştirel-Bilinçli Sevgi Eğitimi. Burdur Eğitim Fakültesi Dergisi, 8(12), $144-152$.

ERGÜN, M. (1987). Satı Bey Hayatı ve Türk Eğitimine Hizmetleri. İnönü Üniversitesi Sosyal Bilimler Dergisi, 1, 4-19.

FORTNA, B. J. (2005). Mekteb-i Hümayûn-Osmanlı İmparatorluğu'nun Son Döneminde İslam, Devlet ve Eğitim. (1. Bask1). (çev. Pelin Siral,). İstanbul: İletişim Yayınları.

GEORGEON, F. (2006). Osmanl-Türk Modernleşmesi 1900-1930. (çev. A. Berktay). (1. Bask1). İstanbul: Yapı Kredi Yayınları.

GIARELli, J. ve JUSTICE, B. (2003). Historia Pro Patria? Philosophy Of Education, 103-106.

GÜVEN, İ. (ed.). (2014). Tarih Öğretimi Kuram ve Uygulama. (2. Bask1). Ankara: Pegem Akademi Yayınları.

GÜVENÇ, B. (2010). Türk Kimliği-Kültür Tarihinin Kaynakları. (2. Baskı). İstanbul: Boyut Yayınları.

HOWLETT, C. F. (2008). John Dewey and Peace Education. Web: www.tc.edu/ centers/ ep e/PDF\%20articles/Howlett_ch3_22feb08.pdf adresinden 11 Ekim 2010 tarihinde alınmıştır.

İNALCIK, H. (2009). Atatürk ve Demokratik Türkiye. (3. Bask1). İstanbul: Kırmızı Yayınları.

KARABAĞ, S. (2009). Coğrafya ve Milli Kimlik. (ed. Çağatay Özdemir) Türk Kimliği içinde (s. 467-490). İstanbul: Ötüken Yayınları.

KARAL, E. Z. (1995). Osmanlı Tarihi-Islahat Fermanı Devri 1861-1876. (5. Bask1). Ankara: TTK Yayınları.

KARPAT, K. (2009). Osmanlı'dan Günümüze Kimlik ve İdeoloji. (çev. G. Ayas,). (2. Bask1). İstanbul: Timaş Yayınları.

KEDOURİE, E. (1971). Avrupa'da Milliyetçilik. (çev. Haluk Timurtaş,), Ankara: Millî Eğitim Basımevi.

KELEŞOĞLU, S. (2008). Demokrat Yurttaş Niteliklerinin Kazandırılması Açısından 7.-8. Sinıf Vatandaşlık ve İnsan Hakları Eğitimi Dersi Programı (2000) ile 6.-7. Sinıf Sosyal Bilgiler Dersi Programının (20005) Karşılaştırılması. Yayımlanmamış Yüksek Lisans Tezi. Ankara: Ankara Üniversitesi Eğitim Bilimleri Enstitüsü.

KODOMAN, B. (1991). Abdülhamid Devri Eğitim Sistemi. (2. Baskı). Ankara: TTK Yayınları.

KUŞÇU, B. (2009). Satı Bey’in Fichte Hakkındaki Görüşleri. Fichte'nin Eğitim Üzerine Düşünceleri ve Türkiye'deki Yansımaları içinde (s. 35-45). (ed. Bahri Ata, Ankara: Pegem Akademi Yayınları. 
LAMACHIA, J. (2001). A Students Guide to American Civics, So What is Patriotism Anyway?. USA: Rosen Publishing.

LANDAU, J. M. (2009). Pan-Türkizm: Dün, Bugün ve Yarın. (çev. B. Sevingen-G. Pultar). (1. Baskı). (ed. Gönül Pultar). Kimlikler Lütfen-Türkiye Cumhuriyeti’nde Kültürel Kimlik Araylşı ve Temsili içinde (s. 79- 86). Ankara: ODTU Yayıncılık.

LAY, J. C. ve PURTA, J. T. (2001). Patriotism and Political Participation Among Russian and American Adolescents. http://www.bsos.umd.edu/gvpt /apwork shop/lay-torneypurta.pdf adresinden 16 Eylül 2010'da alınmıştır.

LEVISOHN, J. A. (2003). Young Patriots or Junior Historians? An Epistemological Defense of Critical Patriotic Education. Philosophy Of Education, 94-102.

LEWIS, B. (2000). Modern Türkiye’nin Doğuşu. (8. Baskı). (çev. M. Kıratlı,). Ankara: TTK Yayınları.

MERRY, M. (2009). Patriotism, History and the Legitimate Aims of American Education. Educational Philosophy and Theory, 41(4), 378-398.

ORTAYLI, İ. (2011). Tarihimiz ve Biz- Osmanlı'yı Yeniden Keşfetmek. (6. Baskı). İstanbul: Timaş Yayınları.

ÖNER, N. (2008). Millî Zihniyet ve Millî Birlik. (der. Ahmet Köklügiller Milliyetçilik Nedir, Ne Değildir? (1. Baskı) içinde (s.261-271). İstanbul: IQ Kültür Sanat Yayıncılık.

ÖZKIRIMLI, U. (2008). Milliyetçilik Kuramları Eleştirel Bir Bakış. Ankara: Doğu Batı Yayınları.

ÖZYÜREK, P. (2006). The Transition of History Education and History Textbooks in Europe From a Nationalist Discourse to a Wider European-Ness Discourse. The Degree of Master of Science. School of Arts and Social Sciences, Sabanci University, İstanbul

PINGEL, F. (2003). Avrupa Evi Ders Kitaplarında 20. Yüzyıl Avrupa'sı. (çev. Nurettin Elhüseyni,). İstanbul: Türkiye Ekonomik ve Toplumsal Tarih Vakfi Yayınları.

PORATH, B. (2007). Civic Virtue Out Of Necessity Patriotism and Democratic Education. Theory and Research in Education, 5(1), 41-59.

RAPOPORT, A. (2009). Lonely Business or Mutual Concern: The Role of Comparative Education in the Cosmopolitan Citisenship Debates. Current Issues in Comparative Education, 12(1), 23-32.

RAATMA, L. (2000). Character Education Patriotism. Minnesota: Capstore Press.

SAFRAN, M. (2002). Türk Tarih Öğretimi ve Meseleleri. (ed. Hasan Celal Güzel, Kemal Çiçek, Salim Koca). Türkler Ansiklopedisi 17 içinde (s. 935-942). Ankara: Yeni Türkiye Yayınları.

SAFRAN, M. (2008). Türkiye'de Tarih Eğitimi ve Öğretimi. (ed. Mustafa Safran ve Dursun Dilek). 21. Yüzyllda Kimlik, Vatandaşlık ve Tarih Eğitimi içinde (s.13-20). İstanbul: Yeni İnsan Yayınevi.

SAFRAN, M. ve ATA, B. (1996), Barışçı Tarih Öğretimi Üzerine Çalışmalar. Gazi Üniversitesi Eğitim Fakültesi Dergisi, 18(1), 11-26.

SAKAOĞLU, N. (1999). Cumhuriyet Dönemi Eğitim Tarihi. İstanbul: İletişim Yayınları.

ŞENGÜL, T. (2006). Meşrutiyet'ten Cumhuriyet'e Siyasi Fikir Akımlarının Tarih Eğitimine Yansımaları (1908-1931). Yayımlanmamış Yüksek LisansTezi. Çanakkale: Çanakkale Onsekiz Mart Üniversitesi Sosyal Bilimler Enstitüsü. 
SUNGU, İ. (2002). Tarih Öğretimi Hakkında. (akt. B. Ata). Millî Eğitim Dergisi, 153-154.

SUNGUR, H. (2012). Amerika Birleşik Devletleri'nde Tarih Eğitimi ve Ulusal tarih Standartlarının Oluşturulması. Yayımlanmamış Doktora Tezi. Ankara: Gazi Üniversitesi Eğitim Bilimleri Enstitüsü.

TANERİ, A. (1993). Türk Kavramının Gelişmesi. Ankara: Ocak Yayınları.

TELEGRAPH (2008). "Should Not Be Taught At School". 9 Ekim 2010 tarihinde http://www.telegraph.co.uk/news/uknews/1577253/Patriotism-should-not-be-taught-atschool.html adresinden alınmıştır.

TOLSTOY, L. N. (2011). Yurtseverlik Askerlik ve Itaatsizlik. (1. Baskı), (çev. Ö. Aydın Süer), Ankara: Epos Yayınları

TTK. (1930). Türk Tarihinin Ana Hatları. İstanbul: Devlet Matbaası.

TTK. (1931). Tarih I-Tarihten Evvelki Zamanlar ve Eski Zamanlar. İstanbul: Devlet Matbaas1.

TÜRK, İ. C. (2013). Osmanlı Devletinde Tarih Eğitimi (1839-1922). (1. Bask1). İstanbul: Ar1 Sanat Yayınları.

TÜRKDOĞAN, O. (2005). Türk Ulus-Devlet Kimliği. (1. Bask1). İstanbul: IQ Kültür Sanat Yayıncilik.

TÜRKMEN, F. (2013). Kök-Türk Abidelerinde Milli Kimlik Hassasiyeti. Milli Folklor, 25(97), 31-38.

ULUÇ, Ö. (2012). İmparatorluktan Ulus Devlete Vatandaşlık Halleri: Osmanlı ve Türkiye'de Vatandaşlık Politikaları. Toplum Bilimleri, 6(12), 7-30.

ÜLKEN, H. Z. (1998). Türkiye'de Çağdaş Düşünce Tarihi. (5. Bask1). İstanbul: Ülken Yayınları.

ÜSTEL, F. (2004). Makbul Vatandaş'ın Peşinde: II. Meşrutiyet'ten Bugüne Vatandaşlık Eğitimi. (1. Basım). İstanbul: İletişim Yayınları.

VATANDAŞ, C. (2004). Ulusal Kimlik Türk Ulusçuluğunun Doğuşu. (1. Baskı). İstanbul: Aç1lım Kitap.

WALKENHORST, H. (2004). The Construction of European Identity and the Role of National Educational Systems' - A Case Study on Germany. 08 Eylül 2014 tarihinde http://citeseerx.ist.psu.edu/viewdoc/download?doi=10.1.1.203.1061\&rep=rep1\&type $=p$ df adresinden alınmıştır.

WESLEY, E. B.(2013). Sosyal Bilgilerin Doğası. (1. Baskı). (çev. ed. Cengiz Dönmez). Ankara: Pegem Akademi Yayınları.

VIROLI, M. (1997). Vatan Aşkl-Yurtseverlik ve Milliyetçilik Üzerine Bir Deneme. (1. Bask1). (çev. Abdullah Yılmaz). İstanbul: Ayrıntı Yayınları

YALÇIN, H. C. (2008). Bizde Türkçülük. (der. Ahmet Köklügiller). Milliyetçilik Nedir, Ne Değildir? (1. Baskı) içinde (s. 91-93). İstanbul: IQ Kültür Sanat Yayıncılık.

YAZICI, S. ve YAZICI, F. (2010). Yurtseverlik Eğitimi: Tarih ve Sosyal Bilgiler Öğretmenlerinin Algı, Tutum Ve Eğitimsel Uygulamalarına Yönelik Bir Araştırma. Sosyal Araştırmalar, 3(10), 649-660.

YILDIRIM, S. (2006). TSK Vatandaşlı Bilinci ve Vatan Sevgisi Eğitiminin Analizi. Yayımlanmamış Yüksek Lisans Tezi. Van: Yüzüncü Yıl Üniversitesi Sosyal Bilimler Enstitüsü. 
YILMAZ, S. (2007). Avrupa Birliği'’nin Tarih Eğitimi Yoluyla Oluşturmaya Çalıştığı Yeni Avrupa Kimliği ve Türkiye'nin Bu Yeni Kimliğe Uyum Çalışmaları, Akademik Incelemeler, 2/1, 69-95.

YİNANÇ, M. H. (2011). Millî Tarihimizin İsmi. (ed. Ahmet Şimşek ve Ali Satan). Milli Tarih İnşası içinde (s. 189-196). İstanbul: Tarihçi Kitabevi.

ZAJDA, J. (2007). The New History School Textbooks in the Russian Federation: 1992-2004. Compare: A journal of comparative education, 37(3), 291-306. 